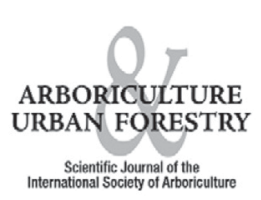

\title{
Withdrawal Resistance of J-Lags from Three Hardwood Species
}

\author{
Brian Kane
}

\begin{abstract}
Cables are commonly installed to reduce the risk of failure of branches or co-dominants, but there are few empirical data to describe their performance. In contrast, the withdrawal resistance of lag screws in timber connections has been studied more carefully and is related to the shank diameter and threaded length of the lag, as well as the specific gravity of the wood. J-lags of three diameters were installed in three species and withdrawal resistance was measured immediately and up to four years after installation. Since only three fully installed J-lags were withdrawn, J-lags were also partially installed in two species. Growth of trees around the "J" of J-lags increased their withdrawal resistance, and the withdrawal resistance of partially installed lags generally followed prediction equations developed for lag screws used in timber connections. Withdrawal resistance of J-lags did not exceed cable tensions previously measured and simulated.

Key Words. Cabling; Decay; J-lag; Tree Support Systems; Withdrawal Resistance.
\end{abstract}

Cables are commonly installed to reduce the risk of failure of branches or co-dominant stems, but there are few empirical data to describe their performance. For example, the ANSI A300 Standard Part 3 Supplemental Support Systems (Anonymous 2006) and its accompanying Best Management Practices guide (Smiley and Lilly 2007) provides appropriate sizes of hardware (J-lags, eyebolts, cable) for various branch diameters, but these guidelines were derived from Thompson $(1935 ; 1936)$, who extracted J-lags immediately after installation in logs approximately $30 \mathrm{~cm}$ in diameter. Although he tested a range of species and shank diameters, Thompson's $(1935 ; 1936)$ work involved only three replicates of each test. Presumably in recognition of the small sample size, Thompson (1936) cautioned that, "Considerably more work is necessary [to] know the most efficient length and diameter of a lag screw for maximum efficiency." Despite this admonition, there appear to be no robust studies on the withdrawal resistance of J-lags in living trees published since Thompson's work.

In contrast, the withdrawal resistance $(\mathrm{P}$, in $\mathrm{N})$ of fasteners (nails, screws, lags, etc.) used in seasoned timber has been studied more carefully (Soltis 1999). For lag screws, which have a hexagonal or square head and are not bent into a "J," Soltis (1999) presented the following equation:

$$
\mathrm{P}=125.4 \mathrm{G}^{1.5} \mathrm{D}^{0.75} \mathrm{~L}
$$

where $G$ is oven-dry specific gravity of the wood, and D and $\mathrm{L}$ are the shank diameter $(\mathrm{mm})$ and thread length $(\mathrm{mm})$ of the lag, respectively. McLain (1997) proposed an alternative prediction equation based on archived data from the USDA FS Forest Products Lab (Newlin and Gahagan 1938), as well as more recently collected data (McLain and Carroll 1990):

$$
\mathrm{P}=185 \mathrm{G}^{1.35} \mathrm{D}^{0.61} \mathrm{~L}
$$

Previous work on lag screws has demonstrated that the principal component of the screw's withdrawal resistance is its thread bearing perpendicular to wood grain; friction between wood and the unthreaded portion of the shank contributes little resistance (McLain 1996). For J-lags installed in trees, however, growth around the unthreaded "J" of the lag may increase withdrawal resistance because the tip of the "J" may be rigidly anchored and resist bending.

Both of these equations assume withdrawal of the lag screw, as opposed to failure of the screw itself, and are based on empirical evidence; there are no theoretical approaches to predict withdrawal resistance (McLain 1996). It is unclear whether tests conducted on timber are relevant to trees, especially considering that most of the empirical work has been conducted on lag screws inserted into samples of clear, straight-grained, seasoned wood. It is also unclear if and how withdrawal resistance of J-lags installed in trees may change over time. As the tree grows around the J-lag, the wood into which the lag was originally installed may simultaneously begin to decay. Predicting this relationship presents a challenge because data to describe discoloration and decay associated with the installation of hardware in trees are anecdotal (Shigo and Felix 1980; Kane and Ryan 2002), with the exception of Dujesiefken et al. (1989) and Smiley (1998).

Considering the potential for liability associated with failure of a cabling system and the dearth of data that quantify withdrawal resistance of J-lags, additional scrutiny is clearly justified. The objectives of this project were to determine the withdrawal resistance with respect to time of J-lags installed in trees and to simulate the effect of wood decay (i.e., wood that offers no withdrawal resistance) by partially installing J-lags in trees.

\section{METHODS AND MATERIALS}

In July 2005, 19 J-lags $9.5 \mathrm{~mm}$ in diameter were installed approximately one meter above ground in red oaks (Quercus rubra 
L.) growing in a row at the Urban Horticulture Center (UHC) in Blacksburg, VA, U.S. (USDA hardiness zone 6B). For red oaks, mean diameter ( \pm standard deviation) at the height of installation was $14.9 \pm 1.49 \mathrm{~cm}$. A pilot hole $1.6 \mathrm{~mm}$ in diameter less than the diameter of the J-lag was drilled into each tree, and J-lags were installed in accordance with the A300 Standard (Anonymous 2006). In September and October 2005, 90 J-lags were installed, divided equally between two shank diameters $(6.4 \mathrm{~mm}$ and $9.5 \mathrm{~mm})$ and in approximately equal proportions between two species [sugar maple (Acer saccharum Marsh.) $(\mathrm{n}=$ 39) and paper birch (Betula papyrifera Marsh.) $(\mathrm{n}=51)$ ] growing in a forest in Pelham, MA, U.S. (USDA hardiness zone 5A). On sugar maple and paper birch, J-lags were installed approximately $1.5 \mathrm{~m}$ above ground. Mean diameter ( \pm standard deviation) of sugar maples and birches into which J-lags $6.4 \mathrm{~mm}$ in diameter were installed was $8.9 \pm 0.95 \mathrm{~cm}$ and $8.7 \pm 1.31 \mathrm{~cm}$, respectively. Mean diameter ( \pm standard deviation) of sugar maples and birches into which J-lags $9.5 \mathrm{~mm}$ in diameter were installed was $24.6 \pm 8.16 \mathrm{~cm}$ and $18.7 \pm 4.72 \mathrm{~cm}$, respectively. At the UHC, all J-lags were withdrawn after one year because the trees were being removed for a new research project. At the site in Pelham, MA, J-lags from trees of both species were removed in the autumn of 2006, 2007, and 2009; in autumn $2008 \mathrm{~J}$-lags were removed from only paper birches. In January 2010 at the site in Pelham, additional trees of both species were harvested and $30 \mathrm{~J}$-lags $12.7 \mathrm{~mm}$ in diameter were installed and immediately extracted. Mean diameter ( \pm standard deviation) of sugar maples and birches into which J-lags $12.7 \mathrm{~mm}$ in diameter were installed was $43.2 \pm 1.18 \mathrm{~cm}$ and $39.8 \pm 0.61 \mathrm{~cm}$, respectively.
After trees were felled, a $\log (0.6 \mathrm{~m}$ long) that was centered on the J-lag was removed from each tree. A paraffin coating was applied to the cut ends of logs, which were then stored for up to 30 days at $4.5^{\circ} \mathrm{C}$ prior to testing. Logs were removed from refrigeration and exposed to room temperature $\left(22^{\circ} \mathrm{C}\right)$ for one hour immediately before testing, but wood temperature at the time of testing was not measured. Logs were secured in a universal testing machine (Figure 1a) (Model 30/G, MTS, Eden Prairie, MN, U.S.) to ensure that the apex of the "J" of the lag was in line with a tensile load applied at $5.1 \mathrm{~mm} / \mathrm{min}$. until the J-lag withdrew from the wood (withdrawal) or failed without withdrawing (lag failure). To apply the load, a hardened steel bolt similar in diameter to the cable that would typically be used with each size lag being tested was fastened between two ends of a chain (Figure 1b). The maximum load as well as the shank diameter and embedded thread length of the J-lag were recorded. A cube of wood $25 \mathrm{~mm}$ on a side was cut from each log near the J-lag, and its mass and volume were measured immediately after testing, as well as after drying in an oven at $50^{\circ} \mathrm{C}$ for three days to attain approximately $12 \%$ moisture content. From these measurements, moisture content and oven-dry specific gravity of the wood were calculated as described by Simpson and TenWolde (1999).

In the winter of 2006-2007, after attempting to withdraw J-lags installed in 2005, it was apparent that lags failed, rather than withdrawing from the logs. Consequently, 66 additional J-lags were installed, divided nearly equally between lags 6.4 $\mathrm{mm}(\mathrm{n}=43)$ and $9.5 \mathrm{~mm}(\mathrm{n}=38)$ diameter in fresh logs from sugar maple $(n=34)$ and paper birch $(n=32)$. J-lags were installed to three partial thread lengths: $12.7 \mathrm{~mm}, 25.4 \mathrm{~mm}$, and

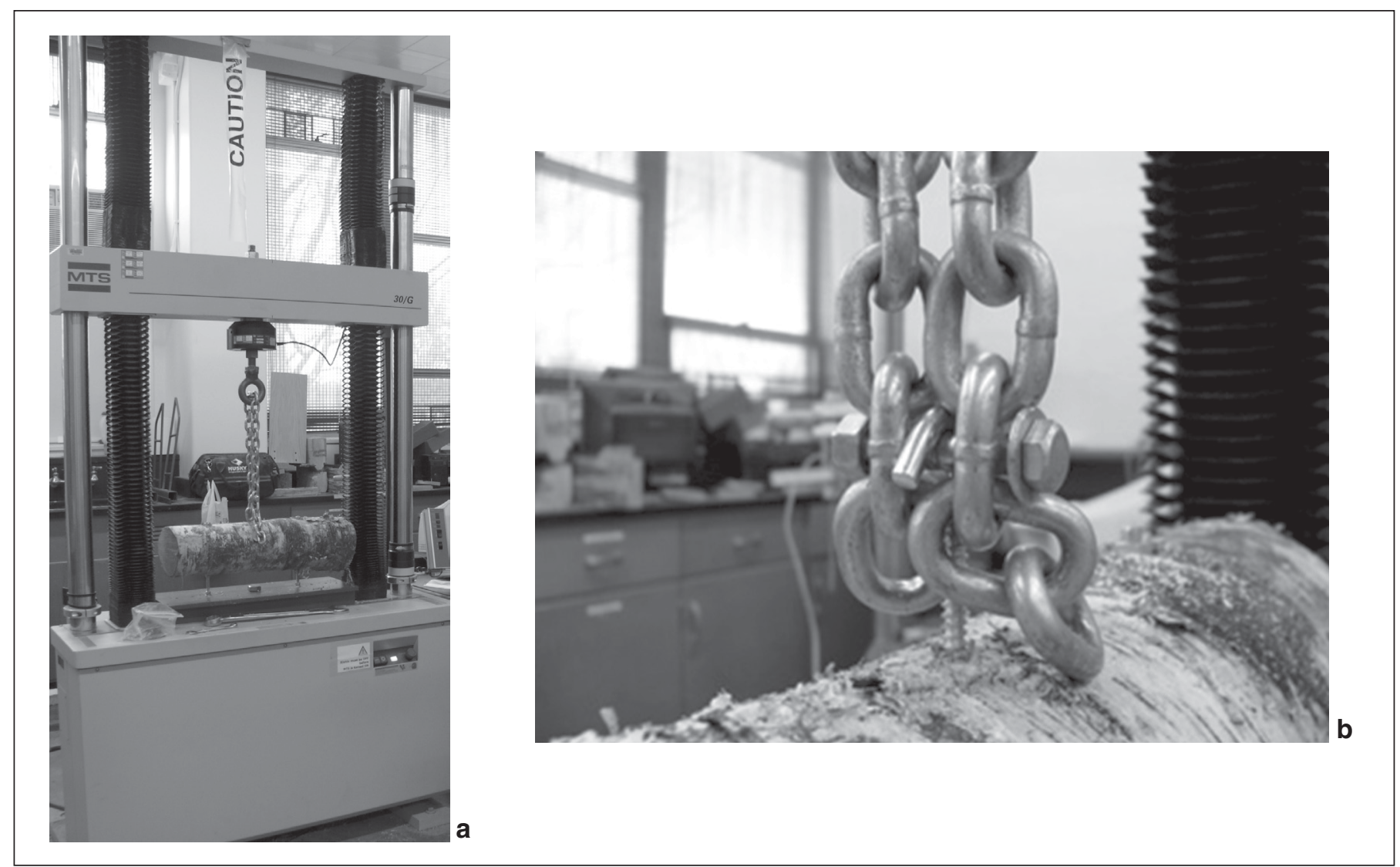

Figure 1. a) Bolt of wood secured to testing machine, and b) partially installed lag being withdrawn. 
$31.8 \mathrm{~mm}$, as well as full thread length $(59.0 \mathrm{~mm}$ and $69.0 \mathrm{~mm}$ for lags $6.4 \mathrm{~mm}$ and $9.5 \mathrm{~mm}$ in diameter, respectively) and immediately tested as previously described. Since ultimate tensile stress of lag screws is achieved when screws are inserted to a thread length 7 times the shank diameter for wood with specific gravity greater than 0.61 (Soltis 1999), an upper bound of partial thread length less than the predicted value was chosen. J-lags were not partially installed in red oaks. Partial installations provided data to compare withdrawal resistance to that predicted from Equations 1 and 2; they also indirectly simulated the effect of decay on withdrawal resistance. For J-lags $12.7 \mathrm{~mm}$ in diameter, tests involving full and partial installations in fresh logs of sugar maple and paper birch were repeated, but the thread lengths were $25.0 \mathrm{~mm}, 50.0 \mathrm{~mm}, 75.0 \mathrm{~mm}$, and $100 \mathrm{~mm}$ (the latter value corresponded to fully-installed J-lags) to accommodate the greater overall thread length of J-lags $12.7 \mathrm{~mm}$ in diameter.

After testing each lag, a disc (approximately 40-50 mm thick) that included the cross-section of the bolt in which the lag had been installed was cut from the log. Including a ruler for scale, a digital image of each disc was taken. If the amount of discoloration appeared to vary between the two cross-sectional surfaces of the disc, the digital image was taken of the surface with a greater amount of discoloration, estimated visually. Unless an area of discoloration was visually distinct from the installation of the J-lag, all discoloration was assumed to be due to installation of the Jlag. Several images of poor quality were not analyzed. The Raster Design extension in AutoCAD 2010 (AutoDesk, Inc., San Rafael, CA, U.S.) was used to scale images of each cross-section (saved as .tiff files) and to delineate the extent of discoloration associated with installation of the J-lag from hand-digitized polylines along the edge of the discolored area. For each delineated polygon, the "measuregeom" command was used to calculate its area and perimeter. The difference between the measured area of discoloration and the area of the hole into which the J-lag was inserted was divided by the latter to calculate the percent increase in area of discoloration beyond the discoloration associated with drilling the hole. While most cross-sections exhibited discoloration corresponding to the hole drilled to install J-lags, probing the crosssections with an awl did not reveal decay in any cross-section.

For fully-installed J-lags 6.4 and $9.5 \mathrm{~mm}$ in diameter, a threeway analysis of variance (ANOVA) was used to investigate the effects of time (in years after installation), shank diameter, and species on the strength of the lags. Shank diameter and species were nested within year because no J-lags were tested in sugar maple in year three, and only one J-lag $6.4 \mathrm{~mm}$ in diameter was tested in year four. Since J-lags installed in red oaks came from a different site, they were not included in the ANOVA, but descriptive statistics for qualitative comparison were presented where appropriate. A similar approach was taken for fully-installed J-lags $12.7 \mathrm{~mm}$ in diameter, since they were only extracted immediately after installation. For all partially-installed J-lags, withdrawal resistance was divided by $\mathrm{G}^{1.35}$ (from Equation 2) to normalize comparisons. A three-way ANOVA was used to compare normalized withdrawal resistance (NWR) among species, shank diameter, and thread length (which was nested within shank diameter because J-lags $12.7 \mathrm{~mm}$ in diameter were partially-installed to different thread lengths than those $6.4 \mathrm{~mm}$ and $9.5 \mathrm{~mm}$ in diameter). Tukey's Honestly Significant Difference (HSD) test (and the Tukey-Kramer adjustment for uneven sample sizes) was used for multiple comparisons of significant $(P<0.05)$ treatments. For significant interactions, the 'slice' statement in the GLM procedure was used to test for differences between levels of one main effect within another. A t-test was used to compare specific gravity between sugar maple and paper birch. Where significance tests included disparate sample sizes and/or nested effects, least squares means were presented. Predictions of withdrawal resistance of partially-installed lags from Equation 1 and Equation 2 were compared with measured values by calculating the percent difference: (predicted - measured) / predicted. Three J-lags 12.7 $\mathrm{mm}$ in diameter installed to $75 \mathrm{~mm}$ thread length in sugar maples failed rather than withdrawing; three J-lags $12.7 \mathrm{~mm}$ in diameter fully installed in paper birch withdrew rather than failed. All of these J-lags were removed from quantitative analyses. All analyses were conducted in SAS (ver. 9.2, Cary, NC, U.S.).

\section{RESULTS}

Mean moisture content ( \pm standard error) of sugar maple (64\% $\pm 0.6 \%, \mathrm{n}=91)$ was less than $(\mathrm{p}<0.0001)$ paper birch $(79 \%$ $\pm 1.0 \%, \mathrm{n}=95)$, but moisture content for all bolts [including red oak $(67 \% \pm 0.8 \%, \mathrm{n}=19)]$ remained well above fiber saturation point $(25 \%-30 \%$ moisture content) throughout the tests. Mean oven-dry specific gravity ( \pm standard error) of sugar maple $(0.67 \pm 0.004, \mathrm{n}=91)$ was greater than $(\mathrm{p}<$ $0.0001)$ paper birch $(0.55 \pm 0.004, \mathrm{n}=95)$. Mean moisture content $( \pm$ standard error) of red oak $(n=19)$ was $0.72 \pm 0.012$.

\section{Fully Installed J-lags}

For J-lags 6.4 and $9.5 \mathrm{~mm}$ in diameter, no fully-installed lags were withdrawn, irrespective of species and the number of years after installation. Instead, all J-lags straightened or, in four cases, failed at the point where the lag protruded from the trunk, just beneath the bark (the same point at which the thread began on the shank). The load at which J-lags 6.4 and $9.5 \mathrm{~mm}$ in diameter failed was greater one or more years after installation than J-lags tested immediately after installation, but that was the only difference (Table 1a). For J-lags $9.5 \mathrm{~mm}$ in diameter withdrawn one year after installation, mean strength of J-lags in red oaks $(8.04 \mathrm{kN})$ was similar to that of J-lags in sugar maple (7.90 $\mathrm{kN})$ and paper birch $(7.78 \mathrm{kN})$. As expected, J-lags $9.5 \mathrm{~mm}$ in diameter consistently failed at greater loads than lags $6.4 \mathrm{~mm}$ in diameter (Table 1b). J-lags 6.4 and $9.5 \mathrm{~mm}$ in diameter installed in sugar maple and paper birch failed at similar loads when tested immediately, as well as one or two years after installation (Table 1c). There were insufficient tests of sugar maple in year three and paper birch in year four for valid comparison between species (Table 1c). For J-lags tested immediately after installation, the least squares mean load ( \pm standard error) at which J-lags $12.7 \mathrm{~mm}$ in diameter failed $(20.3 \pm 0.41 \mathrm{kN})$ was greater than $(\mathrm{p}<0.0001)$ that of J-lags both $9.5 \mathrm{~mm}$ in diameter $(7.84 \pm 0.41 \mathrm{kN})$ and $6.4 \mathrm{~mm}$ in diameter $(3.73 \pm 0.36 \mathrm{kN})$.

\section{Partially Installed J-lags}

Equation 1 and Equation 2 over-predicted withdrawal resistance of partially-installed J-lags by an average of $51 \%$ and $58 \%$, respectively. NWR increased with increasing shank diameter (Table 2a), and with increasing thread length within each shank diameter (Table $2 b)$. Least squares mean NWR ( \pm standard error) was also greater $(\mathrm{p}=0.0020)$ for sugar maple $(11.1$ 
Table 1. Least squares (LS) means (followed by the standard error in parentheses) to induce failure of J-lags ( $\left.P_{\text {MAx }}\right)$ classified by (a) years after installation, (b) shank diameter ( $\mathrm{mm}$ ), and (c) species (sugar maple (AS) and paper birch (BP)). In the ANOVA, shank diameter and species were nested within year.

\begin{tabular}{|c|c|c|c|c|c|c|c|c|}
\hline \multicolumn{3}{|c|}{ (a) } & \multicolumn{3}{|c|}{ (b) } & \multicolumn{3}{|c|}{ (c) } \\
\hline Years & $\mathrm{n}$ & $\mathrm{P}_{\operatorname{MAX}}{ }^{2}(\mathrm{kN})$ & $\begin{array}{l}\text { Shank } \\
\text { Diameter }\end{array}$ & $\mathrm{n}$ & $\mathrm{P}_{\text {MAX }}{ }^{\mathrm{y}}(\mathrm{kN})$ & Species & $\mathrm{n}$ & $\mathrm{P}_{\text {MAX }}{ }^{\mathrm{y}}(\mathrm{kN})$ \\
\hline \multirow[t]{2}{*}{0} & 14 & $5.78(0.09) \mathrm{a}$ & 6.4 & 8 & $3.73(0.12) \mathrm{a}$ & $\mathrm{AS}$ & 7 & $5.80(0.13) \mathrm{a}$ \\
\hline & & & 9.5 & 6 & $7.84(0.13) b$ & $\mathrm{BP}$ & 7 & $5.77(0.13) \mathrm{a}$ \\
\hline \multirow[t]{2}{*}{1} & 29 & $6.24(0.06) b$ & 6.4 & 14 & $4.08(0.09) \mathrm{a}$ & AS & 14 & $6.29(0.09) \mathrm{a}$ \\
\hline & & & 9.5 & 15 & $8.40(0.09) b$ & $\mathrm{BP}$ & 15 & $6.19(0.09) \mathrm{a}$ \\
\hline \multirow[t]{2}{*}{2} & 34 & $6.11(0.06) b$ & 6.4 & 17 & $3.93(0.08) \mathrm{a}$ & AS & 17 & $6.09(0.08) a$ \\
\hline & & & 9.5 & 17 & $8.29(0.08) b$ & $\mathrm{BP}$ & 17 & $6.13(0.08) \mathrm{a}$ \\
\hline \multirow[t]{2}{*}{3} & 17 & $6.15(0.09) b$ & 6.4 & 13 & $4.05(0.09) \mathrm{a}$ & AS & 0 & $\mathrm{n} / \mathrm{a}^{\mathrm{x}}$ \\
\hline & & & 9.5 & 4 & $8.26(0.17) b$ & $\mathrm{BP}$ & 17 & $6.15(0.09)$ \\
\hline \multirow[t]{2}{*}{4} & 10 & $6.44(0.20) b$ & 6.4 & 1 & $\mathrm{n} / \mathrm{a}^{\mathrm{x}}$ & AS & 8 & $6.89(0.18)$ \\
\hline & & & 9.5 & 9 & $8.62(0.13)$ & $\mathrm{BP}$ & 2 & $\mathrm{n} / \mathrm{a}^{\mathrm{x}}$ \\
\hline
\end{tabular}

${ }^{\mathrm{z}}$ For each year, LS means followed by the same letter are not significantly different $(P>0.05)$ by Tukey's HSD test.

${ }^{y}$ LS means for each level of shank diameter and species within each year followed by the same letter are not significantly different $(P>0.05)$ by Tukey's HSD test. ${ }^{x} \mathrm{n} / \mathrm{a}$ indicates that insufficient measurements were made for valid comparison.

$\pm 0.23 \mathrm{kN}, \mathrm{n}=46)$ than paper birch $(10.3 \pm 0.24 \mathrm{kN}, \mathrm{n}=41)$. This difference was not apparent when NWR between species was compared within each shank diameter (data not presented).

\section{Area of Discoloration}

The percent increase in area of discoloration was greatest for Jlags installed four years prior to harvest (Table 3a). Surprisingly, the percent increase in area of discoloration was greater for J-lags installed three years prior to harvest compared to lags installed two years prior, but not compared to lags installed one year prior to harvest (Table 3a). Within each year for which valid comparisons could be made, the percent increase in area of discoloration was similar for sugar maple and paper birch, with the exception of year four (Table 3b). Within each year for which valid comparisons could be made, the percent increase in area of discoloration was similar for J-lags 6.4 and $9.5 \mathrm{~mm}$ in diameter (Table 3c).

\section{DISCUSSION}

In sugar maple and paper birch, even four years after installation, fully installed J-lags 6.4 and $9.5 \mathrm{~mm}$ in diameter failed rather than withdrew from the wood. Even though Thompson (1936) installed and immediately tested lags, his data for several species also revealed that J-lags $6.4 \mathrm{~mm}$ in diameter failed rather than withdrew. However, J-lags $9.5 \mathrm{~mm}$ in diameter withdrew from yellow poplar (Liriodendron tulipifera L.) (Thompson 1936), presumably because of the low specific gravity of the wood of that species. For J-lags installed in lead holes that were $1.6 \mathrm{~mm}$ diameter smaller than shank diameter, Thompson (1936) extracted more J-lags when shank diameters were larger. This is consistent with the finding that fully-installed J-lags $12.7 \mathrm{~mm}$ in diameter withdrew from birch (which had a lower specific gravity) but not sugar maple.

Growth of the tree over the blunt end of the bent section of the lag presumably accounted for the greater failure strength of lags tested one or more years following installation, because previous work has shown that withdrawal resistance of lag screws in timber was similar regardless of whether they were immediately extracted or extracted a year after installation, as long as moisture content did not change (Cizek and Richolson 1957, cited in McLain 1997). J-lags that failed did so by bending (Figure 3), and trunk growth would obviously offer some resistance to deformation of the lag under load. Counter-intuitively, however, this effect did not increase over time. Although growth was not quantified, Jlags tested four years after installation appeared to be more deeply covered by trunk growth than those in year one; for some, the steel bolt (Figure 1b) barely fit through the " $\mathrm{J}$ " of the lag during testing. This observation suggests that while an increment of growth subsequent to installation provides some resistance to bending of the $\mathrm{J}$-lag, additional growth may not offer meaningfully more resistance. Once new growth fully covers a J-lag, it is unclear whether greater resistance to failure would accrue because of fatigue in the cable itself. Future work could investigate this by installing cables with J-lags (or eyebolts) and testing the entire system.

The overestimation of withdrawal resistance of partially-installed lags by Equations 1 and 2 can most likely be attributed to the effect of moisture content of the wood. Predicted withdrawal resistance of lag screws is based on oven-dry timber (12\% moisture content), and the withdrawal resistance of lag screws in wood with moisture content greater than $19 \%$ must be reduced by $33 \%$ (Soltis and Ritter 1996). Cockrell (1933, cited in McLain 1996) observed a 50\% decrease in withdrawal resistance of green wood compared to oven-dried wood. Despite the overestimation, withdrawal resistance of partiallyinstalled lags generally followed the predictions of Equations 1 and 2 (Figure 4): withdrawal resistance increased with shank diameter, thread length and specific gravity (for the latter, it was evident in the lack of difference of NWR between species).

Considering the presumed effect of moisture content in reducing withdrawal resistance as well as the fact that ultimate tensile stress in lag screws $12.7 \mathrm{~mm}$ in diameter would be obtained when thread length equals $88.9 \mathrm{~mm}$ for wood with specific gravity greater than 0.61 (Soltis 1999), it was not expected that any partially-installed lags would fail (as occurred with three J-lags 12.7 $\mathrm{mm}$ in diameter installed to a thread length of $75 \mathrm{~mm}$ in sugar maple). This discrepancy can be attributed to the effect of bending stress on the J-lag as described earlier, and, perhaps, because mean specific gravity of sugar maple was $9.8 \%$ greater than 0.61 .

Partial installation of J-lags offers some insight into the effect of decay on withdrawal resistance, with one important caveat: partially-installed J-lags of all diameters appeared to bend at the point of insertion into the wood more than fully-installed lags. This was expected because the load was applied offset to the threaded portion of the lag, and a longer distance between the point at which the load was applied and the point of insertion 
Table 2. Least squares (LS) means (standard error) of normalized withdrawal resistance (NWR) (kN) of paper birch and sugar maple classified by (a) shank diameter $(\mathrm{mm})$ and $(b)$ thread length $(\mathrm{mm})$ nested within shank diameter.

\begin{tabular}{|c|c|c|c|c|c|}
\hline \multicolumn{3}{|c|}{ (a) } & \multicolumn{3}{|c|}{ (b) } \\
\hline Shank Diameter & $\mathrm{n}$ & $\mathrm{NWR}^{\text {zy }}$ & Thread Length & $\mathrm{n}$ & $\mathrm{NWR}^{\mathrm{x}}$ \\
\hline \multirow[t]{3}{*}{6.4} & 35 & $5.12(0.36) \mathrm{a}$ & 12.7 & 11 & $2.68(0.43) \mathrm{a}$ \\
\hline & & & 25.4 & 14 & $6.02(0.38) b$ \\
\hline & & & 31.8 & 10 & $6.65(0.48) \mathrm{c}$ \\
\hline \multirow[t]{3}{*}{9.5} & 31 & $7.08(0.38) b$ & 12.7 & 8 & $2.99(0.51) \mathrm{a}$ \\
\hline & & & 25.4 & 14 & $7.55(0.38) b$ \\
\hline & & & 31.8 & 9 & $10.7(0.48) \mathrm{c}$ \\
\hline \multirow[t]{3}{*}{12.7} & 21 & $20.9(0.43) \mathrm{c}$ & 25.0 & 8 & $11.2(0.53) \mathrm{a}$ \\
\hline & & & 50.0 & 8 & $22.1(0.53) b$ \\
\hline & & & 75.0 & 5 & $26.4(0.66) \mathrm{c}$ \\
\hline
\end{tabular}

${ }^{2} \mathrm{NWR}=\mathrm{P}_{\mathrm{MAx}} / \mathrm{G}^{1.35}$

${ }^{y}$ For each shank diameter, LS means followed by the same letter were not significantly different $(\mathrm{p}>0.0001)$ by Tukey's HSD test.

${ }^{x}$ LS means for each level of thread length within each year followed by the same letter were not significantly different ( $\left.\mathrm{p}>0.0001\right)$ by Tukey's HSD test.

Table 3. Least squares (LS) means (standard error) of the percent increase in area of discoloration (Area) associated with lag installation classified by (a) years that lags remained in trees prior to harvest, (b) species (sugar maple (AS), paper birch (BP)), and $(c)$ shank diameter $(\mathrm{mm})$. Species and shank diameter were nested within year.

\begin{tabular}{|c|c|c|c|c|c|c|c|c|}
\hline \multicolumn{3}{|c|}{ (a) } & \multicolumn{3}{|c|}{ (b) } & \multicolumn{3}{|c|}{ (c) } \\
\hline Years $^{2}$ & $\mathrm{n}$ & Area $^{y}$ & Species $^{x}$ & $\mathrm{n}$ & Area & Shank Diameter ${ }^{x}$ & $\mathrm{n}$ & Area \\
\hline \multirow[t]{2}{*}{1} & \multirow{2}{*}{16} & \multirow{2}{*}{$192(30.3) \mathrm{ab}$} & AS & 10 & 158 (33.9)a & 6.4 & 4 & $246(52.0) \mathrm{a}$ \\
\hline & & & $\mathrm{BP}$ & 6 & $226(45.5) \mathrm{a}$ & 9.5 & 12 & $139(29.4) \mathrm{a}$ \\
\hline \multirow[t]{2}{*}{2} & \multirow[t]{2}{*}{33} & \multirow[t]{2}{*}{$115(17.5) \mathrm{b}$} & AS & 16 & $97.9(25.6) \mathrm{a}$ & 6.4 & 16 & $100(25.6) \mathrm{a}$ \\
\hline & & & $\mathrm{BP}$ & 17 & $133(25.0) \mathrm{a}$ & 9.5 & 17 & $130(25.0) \mathrm{a}$ \\
\hline \multirow[t]{2}{*}{3} & \multirow[t]{2}{*}{18} & \multirow{2}{*}{$213(28.5) \mathrm{a}$} & AS & 0 & $\mathrm{n} / \mathrm{a}^{\mathrm{w}}$ & 6.4 & 14 & $240(26.9) \mathrm{a}$ \\
\hline & & & $\mathrm{BP}$ & 18 & $213(28.5)$ & 9.5 & 4 & $186(50.3) \mathrm{a}$ \\
\hline & & $422(61.6) \mathrm{c}$ & $\mathrm{BP}$ & 2 & $620(89.2) \mathrm{b}$ & 9.5 & 9 & $420(40.3)$ \\
\hline
\end{tabular}

${ }^{z}$ For each year, LS means followed by the same letter were for not significantly different $(P>0.05)$ by Tukey's HSD test

${ }^{y}$ Area was calculated as percent increase from the hole drilled to insert the lag: (area of discoloration - area of drilled hole) / area of drilled hole.

${ }^{x}$ LS means for each level of species and shank diameter within each year followed by the same letter were for not significantly different $(P>0.05)$ by Tukey's HSD test.

${ }^{\mathrm{w}} \mathrm{n} / \mathrm{a}$ indicates that insufficient measurements were made for valid comparison.

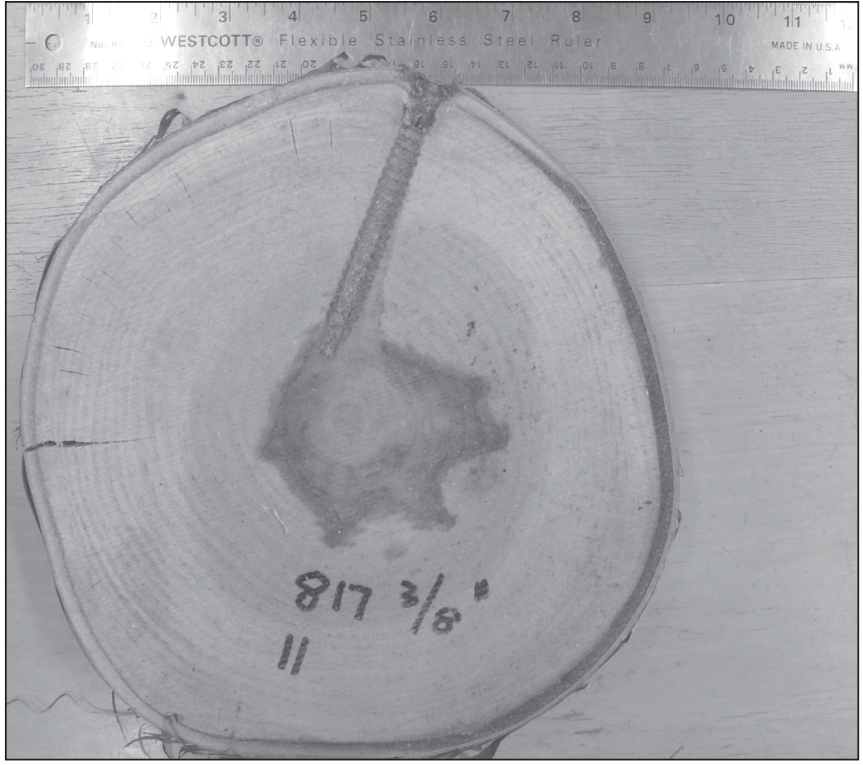

Figure 2. Cross-section of paper birch that had the maximum percent increase in area of discoloration associated with lag installation.

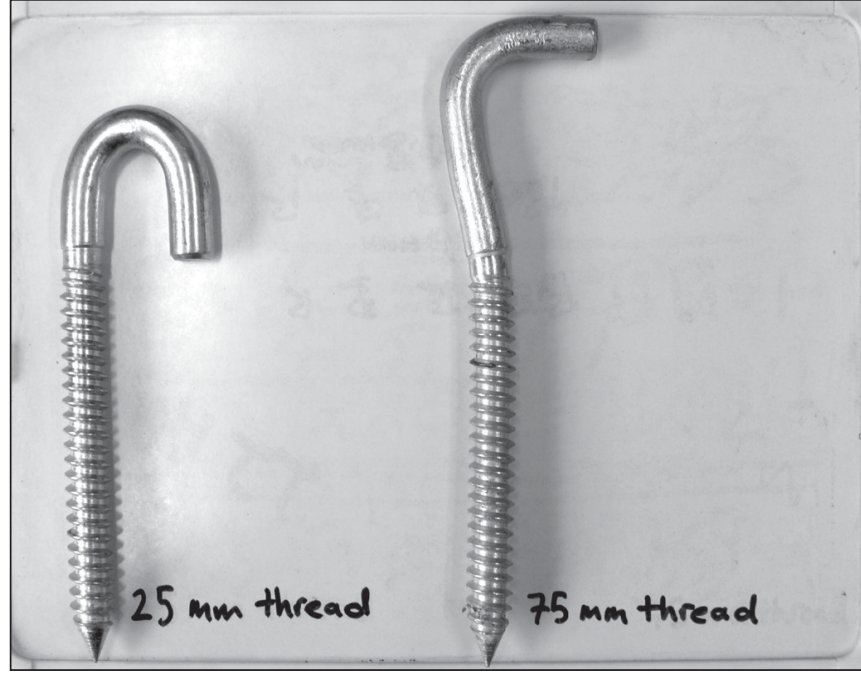

Figure 3. Lags $12.7 \mathrm{~mm}$ in diameter partially-installed in sugar maples that withdrew (left) and failed in bending (right). Thread length to which each lag was installed is written to the right of the lag. 
of the lag into the wood would cause a greater bending moment once the lag shifted its direction to align with the load. Although a) the offset loading mimics the load endured when the J-lag is under tension from a cable, and b) decay renders some thread length ineffective since the wood offers minimal bearing resistance, a fully-installed lag subject to decayed heartwood likely would not bend as much as the partially-installed lags at the point of insertion. Thus, the withdrawal resistance of partiallyinstalled J-lags may be less than offered by fully-installed lags subject to decayed heartwood. In practice, it seems prudent to accept this probable underestimate as a safety factor. Future work should directly investigate the withdrawal resistance of hardware in decayed wood, as opposed to the surrogate data offered here.

Relative to previously reported cable tension or drag on trees, lags provided a substantial safety factor. At wind speeds of approximately $12 \mathrm{~m} / \mathrm{s}$, a load of $4.3 \mathrm{kN}$ was measured in a cable installed between two co-dominant stems in a $29 \mathrm{~m}$ tall sugar gum (Eucalyptus cladocaly $\times$ F. Muell.) (James et al. 2001). This load was considered an aberration; the next largest measured load was $1.2 \mathrm{kN}$ (James et al. 2001). At the same wind speed, a computer simulation of wind-induced movement of a tree with stems 17.8 and $30.5 \mathrm{~cm}$ in diameter predicted a maximum cable tension of 6.4 kN (Greco et al. 2004). On a shingle oak (Quercus imbricaria Michx.) $11 \mathrm{~cm}$ diameter above the root flare, at a wind speed of 22.4 $\mathrm{m} / \mathrm{s}$, the maximum recorded load was $1.2 \mathrm{kN}$ (Kane et al. 2008). None of these loads exceeded the minimum failure load $(7.18 \mathrm{kN})$ of a fully-installed J-lag $9.5 \mathrm{~mm}$ in diameter; and even the $6.4 \mathrm{kN}$ load was less than half the minimum failure load $(14.0 \mathrm{kN})$ of a fully-installed J-lag $12.7 \mathrm{~mm}$ in diameter. According to the A300 Standard (Anonymous 2006), J-lags 9.5 and $12.7 \mathrm{~mm}$ in diameter would be appropriate for the branch and trunk diameters in the studies (James et al. 2001; Greco et al. 2004; Kane et al. 2008). Even partially-installed J-lags of 9.5 and $12.7 \mathrm{~mm}$ in diameter would have neither withdrawn nor failed, except for withdrawal of lags $9.5 \mathrm{~mm}$ in diameter installed to $12.7 \mathrm{~mm}$ of thread length. Assuming branch diameter of $17.8 \mathrm{~cm}$ and concentric decay, the latter exception describes a branch for which $86 \%$ of the crosssection is decayed; an unlikely candidate for cabling, and not one in which J-lags would be used as anchors (Anonymous 2006).

Although several studies have provided qualitative information supporting the notion that discoloration and decay may not be significant in certain species and under certain conditions (Shigo and Felix 1980; Kane and Ryan 2002), it appears that only Smiley (1998) has quantified discoloration associated with drilling to install support systems, and his work specifically addressed countersinking for the installation of eyebolts. The reported percent increase in area of discoloration may be an overestimate because it was assumed that discoloration was associated with installation of J-lags unless areas of discoloration were visibly separate from the lag. A more careful accounting of decay, for example by removing additional discs from each tree one meter above and below the point of installation of the J-lag, might have allowed a more accurate estimation of discoloration associated with the installation of the lag. It was unclear why the percent increase in the area of discoloration was greater in year three

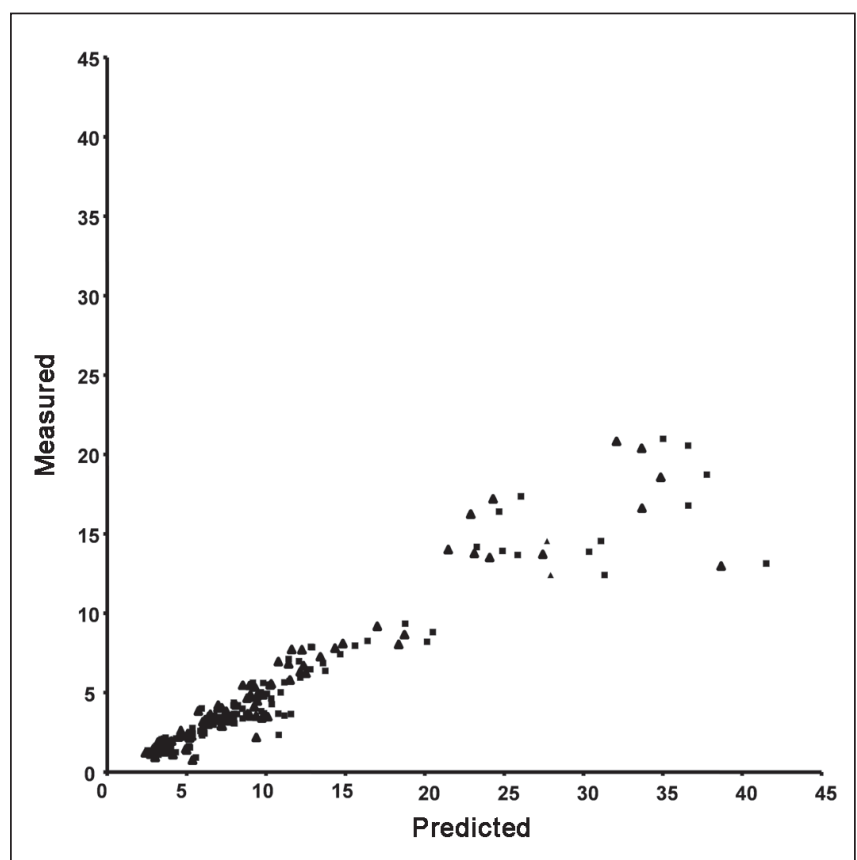

Figure 4. Measured withdrawal resistance $(\mathrm{kN})$ plotted against withdrawal resistance $(\mathrm{kN})$ predicted from equations $1(\Delta)$ and 2 (घ).

compared to year two, but not between years one and three. It may have been attributable to inherent differences between trees with respect to compartmentalization or confounded by the lack of sugar maples tested in year three. While discoloration and decay may be inevitable consequences of installation of hardware in trees, because many factors affect how rapidly and widely decay forms (Smith 2006), considerably more work is necessary.

\section{CONCLUSION}

The results of the present study offer some assurance that, in the absence of decay, lags provide substantial withdrawal resistance in species with moderately dense wood. They also suggest that for paper birch and sugar maple growing in Massachusetts, decay associated with installation of J-lags is minimal after four years. The results, however, should not be applied to other species with different specific gravity values or those predisposed to decay after wounding. Trees of less vigor, even of the same species, might also be more susceptible to decay, or less likely to grow around the J-lag. As Thompson (1936) suggested, considerably more work is necessary on many aspects of tree support systems.

Acknowledgments. The author gratefully acknowledges the following students and staff at the University of Massachusetts-Amherst: Ed Carpenter and Andrew Putnam for installing lags; Dan Pepin for fabricating the testing apparatus; Mac Cloyes, Mollie Freilicher, and Joe Scharf for extracting lags; and Alex Sherman for analyzing images; as well as two anonymous reviewers for many helpful comments on earlier drafts of the manuscript. 


\section{LITERATURE CITED}

Anonymous. 2006. American National Standard: Tree, Shrub and Other Woody Plant Maintenance-Standard Practices (Supplemental Support Systems). American National Standards Institute. New York, NY. $30 \mathrm{pp}$.

Dujesiefken, D., S. Ebenritter, and W. Liese. 1989. Wundreaktionen im Holzgewebe bei Birke Buche und Linde. Holz Roh Werkst 47:495-500.

Greco, C.M., A. Lee, D. Ham, E.T. Smiley, and E.H. Law. 2004. A computer simulation of an alternative design to tree crown support systems. Journal of Arboriculture 30:365-370.

James, K.R., N. Haritos, and P. Kenyon. 2001. Measuring loads on tree limbs and cables. In: E.T. Smiley and K.D. Coder (Eds.). Tree Structure and Mechanics Conference Proceedings: How Trees Stand Up and Fall Down, October 2001, Savannah, GA. International Society of Arboriculture, Champaign, IL. pp. 125-138.

Kane, B.C.P., and H.D.P. Ryan. 2002. Discoloration and decay associated with hardware installation in trees. Journal of Arboriculture 28:187-193.

Kane, B., M. Pavlis, J.R. Seiler, and J.R. Harris. 2008. Crown reconfiguration and trunk stress in deciduous trees. Canadian Journal of Forest Research 38:1275-1289.

McLain, T.E. 1996. Lag Screws and Wood Screws. In: Mechanical Connections in Wood Structures. ASCE Manuals and Reports on Engineering Practice No. 84. American Society of Civil Engineers. New York, NY. 231 pp.

McLain, T.E. 1997. Design axial withdrawal strength from wood. I. Wood screws and lag screws. Forest Products Journal 47:77-84.

McLain, T.E., and J.D. Carroll. 1990. Combined load capacity of threaded fastener-wood connections. Journal of Structural Engineering 116(9):2419-2432.

Newlin, J.A., and J.M. Gahagan. 1938. Lag-screw joinings: their behavior and design. Tech. Bulletin No. 597. USDAFS-FPL, Madison WI. 25 pp.

Shigo, A.L., and R. Felix. 1980. Cabling and Bracing. Journal of Arboriculture 6:5-9.

Simpson, W., and A. TenWolde. 1999. Physical properties and moisture relations of wood. In: Wood Handbook— wood as an engineering material. Gen. Tech. Rep. FPL-GTR-113. Madison, WI, USDA Forest Service Forest Products Laboratory. 463 pp.

Smith, K.T. 2006. Compartmentalization today. Arboricultural Journal $29: 173-184$

Smiley, E.T. 1998. Countersinking for tree bolts. Journal of Arboriculture $24: 245-247$

Smiley, E.T, and S. Lilly. 2007. Tree Support Systems: Cabling, Bracing, Guying, and Propping (Revised). International Society of Arboriculture. Champaign, IL. 35 pp.

Soltis, L.A., and M. Ritter. 1996. Introduction. In: Mechanical Connections in Wood Structures. ASCE Manuals and Reports on Engineering Practice No. 84. American Society of Civil Engineers. New York, NY $231 \mathrm{pp}$.

Soltis, L.A. 1999. Fastenings. In: Wood Handbook-wood as an engineering material. Gen. Tech. Rep. FPL-GTR-113. Madison, WI, USDA Forest Service Forest Products Laboratory. 463 pp.

Thompson, A.R. 1935. Tree Bracing. Tree Preservation Bulletin No. 3. USDI National Park Service 16 pp.

Thompson, A.R. 1936. Tree Cabling Materials. Proceedings of the National Shade Tree Conference. pp. 30-43.

\section{Brian Kane}

MA Arborists Association Professor

Department of Environmental Conservation

University of Massachusetts

Amherst, MA 01003, U.S

Résumé. Des câbles sont communément installés pour réduire les risques de bris de branches ou de fourches, mais il existe peu de données empiriques qui décrivent leur performance. En contrepartie, la résistance au bris des vis d'ancrage dans les tiges a été étudiée avec plus d'attention et est fonction du diamètre de la tige et de la longueur du filetage de cette dernière tout comme la gravité spécifique du bois. Des vis en J de trois diamètres différents ont été installés dans trois espèces différentes et la résistance au bris a été mesurée immédiatement après ainsi que quatre ans après l'installation. Puisque seulement trois vis en J pleinement installées se sont brisées, des vis en J ont aussi été installées partiellement dans deux espèces. La croissance des arbres autour de la portion en J de la vis a accru la capacité de résistance au bris, et la résistance au bris des vis partiellement installées suivaient généralement les équations de prédiction développées pour les vis d'ancrage insérées dans le bois. La résistance au bris des vis en J n'excédait pas la tension du câble telle que mesurée ou simulée.

Zusammenfassung. Gurte werden im allgemeinen in Bäumen installiert, um das Risiko des Versagens von Ästen oder kodominanten Stämmen zu reduzieren. Im Gegensatz dazu ist der Abreisswiderstand der Ankerschrauben in Holzverbindungen viel mehr untersucht worden und wird in Beziehung gesetzt mit dem Schenkeldurchmesser und der Länge der Schraube und auch mit der spezifischen Holzschwere. J-Schrauben mit drei verschiedenen Durchmessern wurden in drei Arten installiert und der Abreisswiderstand wurde beim Einbau und vier Jahre nach der Installation gemessen. Da nur drei voll installierte J-Schrauben gezogen wurden, wurden die J-Schrauben zwei Arten auch teilweise installiert. Das Wachstum der Bäume um die J-Schraube nahm mit dem Abreisswiderstand zu und der Abreisswiderstand der partiell installierten Schrauben folgte den allgemeinen Vorhersagen zum Verhalten dieser Schrauben in Holzverbindungen. Der Abreisswiderstand der J-Schrauben überstieg nicht die vorher gemessenen und simulierten Kabelspannungen.

Resumen. Los cables son instalados comúnmente para reducir los riesgos de fallas de ramas o brazos codominantes, pero hay pocos datos empíricos para describir su comportamiento. En contraste, la resistencia de armellas en conexiones ha sido estudiada más cuidadosamente y está relacionada al diámetro y longitud de la armella, como también a la gravedad específica de la madera. Se instalaron armellas de tres diámetros en tres especies de árboles y se midió la resistencia de la instalación inmediatamente y después de cuatro años. Solamente tres armellas fueron resistentes parcialmente en dos especies. El crecimiento de los árboles alrededor de la "J" incrementó su resistencia y se predijo por ecuaciones desarrolladas para armellas usadas en conexiones de madera. La resistencia de las armellas no excedió las tensiones de cables previamente medidos y simulados. 